\title{
Key Financials Performance Independent versus Integrated: Empirical Evidence from Indonesia Financial Service Industry (2001-2011)
}

\author{
Suwinto Johan ${ }^{1,2}$, Hermanto Siregar ${ }^{1}$,Tubagus Nur Ahmad Maulana ${ }^{1} \&$ Perdana Wahyu Santosa $^{1}$ \\ ${ }^{1}$ Graduate School of Management and Business, Bogor Agricultural University, Indonesia \\ ${ }^{2}$ Graduate School of Management, Tarumanagara University, Indonesia \\ Correspondence: Suwinto Johan, Graduate School of Management and Business, Bogor Agricultural University, \\ Jl Padjajaran, Bogor, Indonesia. Tel: 62-816-917053. E-mail: suwinto@yahoo.com
}

Received: November 5, 2012

Accepted: November 23, 2012

Online Published: December 10, 2012

doi:10.5539/ijef.v5n1p92

URL: http://dx.doi.org/10.5539/ijef.v5n1p92

\begin{abstract}
The aims of the paper are to study the financial performance between the independent finance companies and the integrated finance companies over the period 2001-2011. From total 194 finance companies in the industry, the finance companies who affiliate with bank or automotive manufacturer are 65 companies that contribute to $71 \%$ of total asset of the industry. The banking industry that provides majority of funding, has made finance companies as part of their integration business model. The automotive manufacturers and dealers that provide the products of financing, have the similar strategy. The acquisition of finance companies has reached more than 30 transactions from 2002 until 2012. We analyzed seven micro key financial ratios (profitability, efficiency, growth, firm size, liquidity, solvability and risk). We use non parametric Mann Whitney and parametric Panel Data Dummy Regression. Our sample consists of 100 finance companies which continuously published their financial statement from 2001 until 2011. The empirical results show that the integrated finance companies are better in efficiency, profitability, size and growth. However, the integrated finance company has higher reserve policy and lower liquidity. On the other side, we also compare between the backward integration with bank and the forward integration with automotive manufacturer.
\end{abstract}

Keywords: acquisition, integration, financial industry, panel data

\section{Introduction}

Indonesia finance company industry has evolved from Rp37 trillion in 2001 to Rp221 trillion in 2010 with compounded annual growth rate (CAGR) of $122 \%$. The financing contribution to Indonesia's gross domestic product has reached a value of $3.59 \%$ (Nuryartono 2012). The financing contribution to the total national credit Indonesia reached $12.5 \%$ in 2011.

The finance company industry is highly dependent on two other industries, the banking industry and the automotive industry. Banking industry serves as the major funding source for finance companies, ranging from $78 \%$ to $91 \%$ in the last eight years. This dependence results in a number of finance companies being acquired by banks. Out of the listed top ten banks, there are six banks that made acquisitions over finance companies during the last ten years. Banking, the major banks in particular, utilize finance companies as one of the sources for growth.

Finance company industry is an industry where demand is a derived demand (Hutabarat, 2012). Financing must involve underlying transaction or product and it may not provide financing or loans without any solid occurrence of transaction of goods or services.

Finance companies can be categorized into three major categories, as follows:

1. Finance companies that have affiliate relationships with manufacturers and distributors of goods as a source of financing.

2. Finance companies that have affiliate relationships with banks as a source of funding.

3. Independent finance companies that do not have affiliation either with manufacturer, distributors, or banks.

Figure 1 shows that the group of finance companies that are affiliated with banks control $28 \%$ of total financing amount, while the finance companies affiliated with the automotive manufacturers and dealers control $35 \%$ of total 
financing amount. The number of independent finance companies in terms of quantity, amount to one hundred and fifty-two companies with asset of only $37 \%$.

In line with the increased levels of competition, finance companies will consider going with an alliance or grow independently. If an alliance, finance companies can choose to integrate backward with banks (backward integration) or forward with automotive related companies (forward integration).

Backward integration is a resource-based strategy. The dependence of finance companies on source of funds is important in the competition. Finance company that has a bank parent holding company will enhance the subsidiary to perform more competitively. Forward integration is a market-driven strategy. Finance companies which conduct forward integration will have focused products or captive markets.

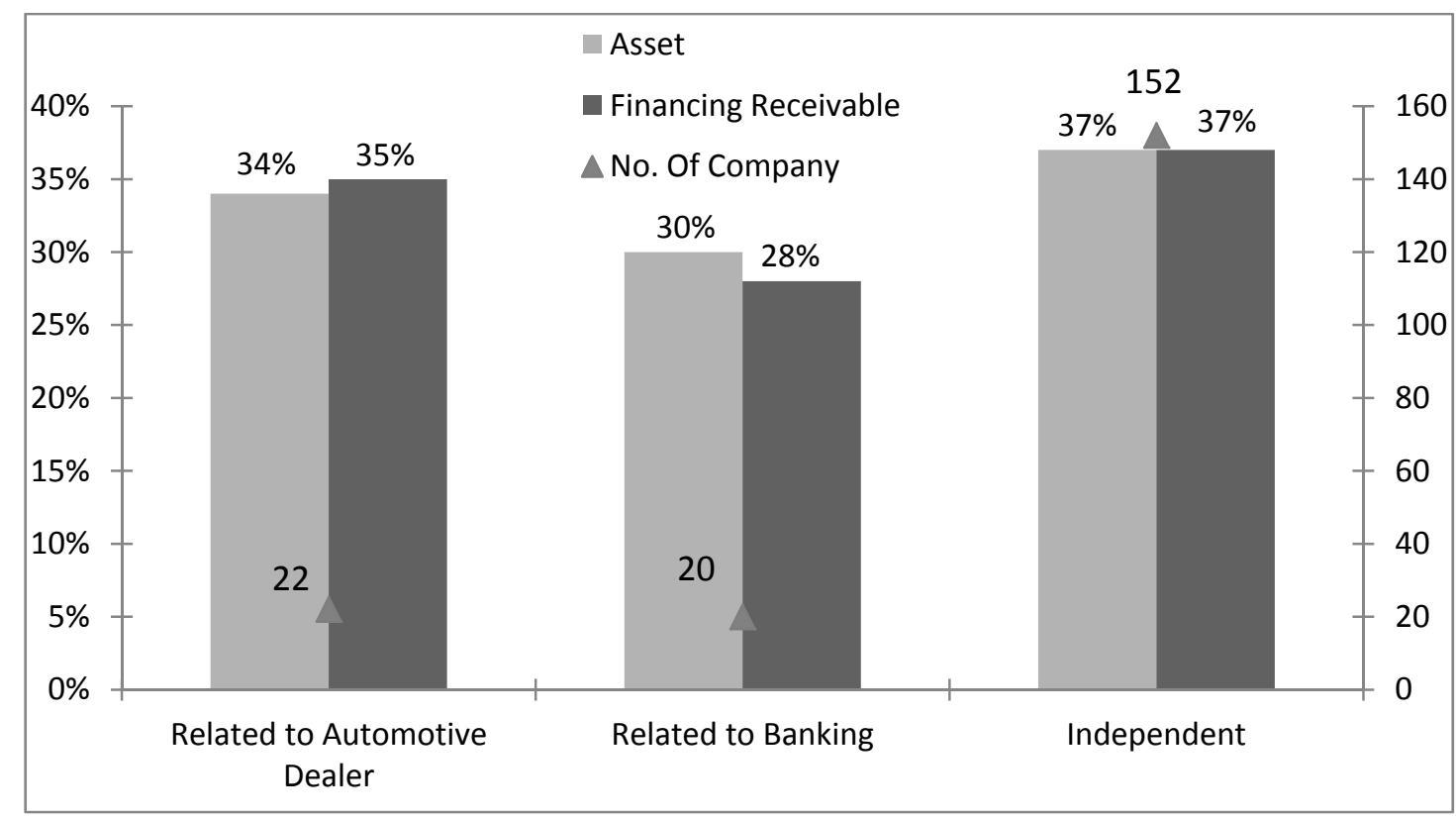

Figure 1. Category of Finance Companies

Source: Indopremier Securities Research (2009)

However, integration also provides limitations on finance companies. Finance companies become dependent on a particular party. The dependence on the parent company for funding support and captive market will reduce finance companies' competitiveness. Financial indicators that are measured in this research include growth ratio, firm size, profitability ratio, efficiency ratio, liquidity ratio, risk ratio and solvency ratio.

This study becomes unique by examining the integration between the three industries which are the finance company industry, the banking industry and the automotive industry. Research on the financial performance difference between integrated and independent industries is still uncommon, especially in developing countries like Indonesia. Among some examples are Healey (1992), Cornet and Tehranian (1992), Akhavein (1997), Berger (1997) Berger, Demzetz, Straham (1999), Berger (2000), Cheng (2006), Wang (2007), Chang (2006), Becalli (2008), Aktas (2008).

Maldenker and Lev (1972) found that companies that do mergers and acquisitions have performed better than companies that do not in the long term. The study measured the total of thirteen financial ratios.

Healey (1992) illustrates that companies who do mergers will have better performance in productivity of assets compared to the industry average. Mergers and acquisitions can change a company's solvency rate, bankruptcy risk or the raw material's price, quality and quantity after the merger (Haugen and Langetieg 1975).

Cornet and Tehranian (1992) researched fifteen acquisition transactions of major banks that do acquisitions as compared to fifteen other major banks that did not do any acquisitions during the years 1982 to 1987 in America. Research results show that banks that do mergers and acquisitions have better performance than the banking industry. Performance improves in obtaining funding, lending, employee productivity and profit growth. 
Akhavein et al. (1997) examines the banking mergers from 1981-1989 with a minimum asset value of $\$ 1$ billion. This study found that the merger has a significant improvement on profit efficiency compared to other major banks. These banks increase revenues, improve efficiency which previously was at a low level, but do not increase prices or yield of the portfolio.

Berger et al. (1997) observed the implications of mergers and acquisitions of financial institutions and lenders as well as competitor reactions to mergers and acquisitions. The research was conducted in the 1970s with a sample of six thousand transactions. This study found that the merger between two small and medium financing institutions will increase lending for Small and Medium Enterprises (SMEs). Meanwhile, the acquisitions made by large financial institutions will lower the credit financing of SMEs. Mergers and acquisitions will change the strategy and focus rather than changing the target of financial companies.

Berge, Demzetz, Straham (1999) obtained positive results in the consolidation of the financial industry, especially in the market competition, earning power and risk diversification. Financial consolidation will reduce the level of efficiency. Berger (2000) also found that the integration of the financial industry will have great potential in efficiency, but only a small amount of release. Integration increases the revenue efficiency compared to cost reduction. Risk diversification lowers the operational costs.

Cheng (2006) found that the consolidation of financial institutions will increase the return on equity and capital adequacy ratio (CAR), deposit growth and loan distribution. Institutional consolidation also lowers employee productivity by measuring total assets divided by the number of employees. Small banks have a more efficient performance and better growth while the big banks have a better ratio of profitability, credit quality and CAR.

Wang (2007) found that capital markets react positively to the alliance of financial companies. After the alliance, financial companies involved in an alliance will perform better than before the alliance occurred. Alliances tend to be joint ventures and mergers. The research was conducted from 1986 to 2003 with a sample of the banking, insurance, finance and securities industry.

Becalli (2008) found that bank mergers and acquisitions achieve efficiencies in its operations when compared to banks that do not do mergers and acquisitions. Healey et al. (1992) conducted a research on fifty mergers and acquisitions done by major companies in the industrial field in America between the years 1979 to 1983. Research results show an increase in the productivity of assets after the merger compared to the industry. Significant improvement occurred on the return on cash flow and companies maintain their investment in capital expenditure investments and research and development after the merger.

Chang et al. (2006) explained that Japanese and American companies that establish alliances will have a positive result within three years after the alliance. This positive performance results mainly in small-scale enterprises, has great growth prospects but whose profits are still below the industry. Wu (2004) found that the merger has a negative effect for the short-term merger than companies that do not merge.

On contrary, Zhang (2006) stated that there is no difference in scale, scope and efficiency of banking products on the consolidated results between the years 1999-2005. Aktas (2008) found that there were no significant differences between companies that conduct organic growth and those that do mergers and acquisitions. In the short term, companies that conduct organic growth will improve operating performance, cost reduction and economies of scale. This research was conducted on companies listed on the stock exchange in the U.S. from 1990-2004.

Langetieg et al. (1980) explained that the merger increases the risk to shareholders in the acquiring company. The merger increases systematic risks, both the total risk and diversification risk on the consolidated company. This study managed to find that the merger brings the risk for the acquiring company. These results have never been found in previous studies. Previous studies considered the merger as part of risk reduction by means of diversification and integration, therefore the merger is considered as one of company's attempt in reducing / decreasing risk. Decline in shareholder value will be reflected by the perfect and complete capital markets in response to the expected profit in appropriate amount. Increased risk in a merger is showed by an increasing on leverage of the post-merger company.

Although there are already numerous researches concerning the performance of an acquisition, there is no conclusive result yet. Therefore, it is important to conduct a research on this topic, especially in a specific industry with acquirers from related industry.

This paper will study the performance of finance company industry in Indonesia during 2001-2011. The performance measurement will be based on the financial performance between integrated and independent finance companies. The financial measurements are grouped into 7 dimensions, which are profitability, efficiency, 
solvency, liquidity, size, growth, and asset quality.

The rest of the paper will be organized as follows, after the introduction, we describe the data and methodology in Section 2, followed by the result and discussion in Section 3. Finally, Section 4 gives summary and conclusion remarks.

\section{Methodology, Variable and Data}

\subsection{Methodology}

\subsubsection{Dummy Variable Regression}

Parametric test model in this study is developed from the dummy regression models by Vennet (2002). To test the financial performance between independent and integrated finance company, the integrated companies are coded differently from independent companies $(\mathrm{DA}=$ dummy). DA code for integrated company $=1$, code for independent company $=0$. Parametric tests are conducted by dummy regression towards each variable by the equation as follows:

Model 1a:

$$
Y_{i t}=a+b_{1} D A_{i t}+\varepsilon
$$

Model 1b:

$$
Y_{i t}=a+b_{1} D A_{i t}+b_{2} F S I_{i t-1}+b_{3} T A G R_{i t-1}+\varepsilon
$$

Note:

$\mathrm{Y}_{\text {it }}=$ EXIR, ROA, ROE, NPM, PROV, LEV, PATA, LIQ, EXPA, REPA, LITA, FSI, TAGR, PAGR, NIGR, REGR, EXGR

$\mathrm{DA}=$ dummy alliance, 1 for integrated and 0 for independent

FSI $=$ Firm Size

TAGR $=$ Total Asset Growth

To test the financial performance between backward and forward integration, the backward integrated companies are coded differently from forward integrated companies (DI = dummy integration). DI code for backward integrated company $=1$, DI code for forward integrated company $=0$. Parametric tests are conducted by dummy regression towards each variable by the equation as follows:

The hypotesis are as follow:

H1:There were differences in growth

$\mathrm{H} 2$ :There were differences in efficiency

H3:There were differences in solvency

H4:There were differences in asset quality

$\mathrm{H} 5$ :There were differences in firm size

H6:There were differences in liquidity

H7:There were differences in profitability

\subsubsection{The Non-parametric Mann Whitney Test}

Non-parametric test model in this study follows the model developed by Chang (2006), Wang (2007) and Hagendorff and Keasey (2009). This research model will focus on the performance difference between the two groups of independent and paired sample. This test aims to test the characteristics between the 2 groups of independent samples. Mann Whitney test is an alternative testing to the $t$ test without any restriction. This test can also apply for a different number of samples tested in the 2 groups.

Mann Whitney U test Formula Test

$$
U=n 1 n 2+\frac{n 1(n 1+1)}{2}-R 1
$$

or

$$
U=n 1 n 2+\frac{n 2(n 2+1)}{2}-R 2
$$

where: 
$\mathrm{n}_{1}=$ number of sample 1

$\mathrm{n}_{2}=$ number of sample 2

$\mathrm{R}_{1}=$ number of ranks of the sample 1

$\mathrm{R}_{2}=$ number of ranks of the sample 2

Non-parametric test performed with Mann Whitney Test

Using $\alpha=5 \%$

- Based on the t-statistics value and p-value, the variables that are significantly different between the integrated and independent companies will be noticeable.

\subsection{Variable and Measurement}

The five ratios were developed by Healey et al. (1992), Cornet and Tehranian (1992, 2004) and Cheng (2006). This study adds in the variable of growth developed by Mandelker (1972) and a variable of size developed by Vennet (2002). These variables are adapted and developed into seven measurement ratio groups with 17 research variables as showed in table 1.

Table 1. Financial Ratios

\begin{tabular}{|c|c|}
\hline Ratio & Formulation \\
\hline \multicolumn{2}{|l|}{ Growth Ratio } \\
\hline Revenue Growth & Revenue $(t)-$ Revenue $(t-1)$ \\
\hline & $R E G R=\frac{\text { Revenue }(t-1)}{2}$ \\
\hline & Total Asset $(t)-$ Total Asset $(t-1)$ \\
\hline Total Asset Growth & TAGR $=\frac{\text { Total Asset }(t-1)}{}$ \\
\hline & $N I G R=\frac{\text { Net Income }(t)-N e t \text { Income }(t-1)}{}$ \\
\hline Net Income Growth & $N I G R=\frac{\text { Net Income }(t-1)}{\text { In }}$ \\
\hline Productive Asset Growth & PAGR $=\frac{\text { Productive Asset }(t)-\text { Productive Asset }(t-1)}{\text { Productive Asset }(t-1)}$ \\
\hline \multicolumn{2}{|l|}{ Efficiency Ratio } \\
\hline Expense Income Ratio & EXIR $=\frac{\text { Expense }}{\text { Income }}$ \\
\hline Expense to Productive Assets & EXPA $=\frac{\text { Expense }}{\text { Productive Asset }}$ \\
\hline Expenses Growth & EXGR $=\frac{\text { Expense }(t)-\text { Expense }(t-1)}{\text { Expense }(t-1)}$ \\
\hline Productive Assets To Total Assets & PATA $=\frac{\text { Proauctive Assel }}{\text { Total Asset }}$ \\
\hline \multicolumn{2}{|l|}{ Solvency Ratio } \\
\hline $\begin{array}{l}\text { Liabilities Total Assets } \\
\text { Leverage Ratio }\end{array}$ & $\begin{array}{l}\text { LITA }=\frac{\text { Total Liablities }}{\text { Total Asset }} \\
\text { LEV }=\frac{\text { Total Liablities }}{\text { Total Equity }}\end{array}$ \\
\hline \multicolumn{2}{|l|}{ Asset Quality } \\
\hline Provisioning Policy & PROV $=\frac{\text { Total Provisioning }}{\text { Total Productive Asset }}$ \\
\hline \multicolumn{2}{|l|}{ Size Ratio } \\
\hline Firm Size & $\begin{array}{l}\mathrm{FSI}_{\mathrm{t}}=\ln \text { Total Asset }(\mathrm{t}) \\
\mathrm{FSI}_{\mathrm{t}-1}=\ln \operatorname{Total} \operatorname{Asset}(\mathrm{t}-1)\end{array}$ \\
\hline \multicolumn{2}{|l|}{ Liquidity Ratio } \\
\hline Liquidity Ratio & LIQ $=\frac{\text { Total Productive Asset }}{\text { Total Liablities }}$ \\
\hline \multicolumn{2}{|l|}{ Profitability Ratio } \\
\hline Return on Assets & ROA $=\frac{\text { Net Income }}{\text { Total Asset }}$ \\
\hline Return on Equity & ROE $=\frac{\text { Total Equity }}{\text { Interest Income }- \text { Cost of Fund }- \text { Expenses }}$ \\
\hline Revenue to Productive Assets Ratio & $\begin{array}{l}N P M=\frac{\text { Interest Income }- \text { Cost of Fund }- \text { Expenses }}{\text { Interest Income }} \\
R E P A=\frac{\text { Revenue }}{\text { Total Productive Asset }}\end{array}$ \\
\hline
\end{tabular}




\subsection{Data}

This study uses secondary data collected from various institutes and official literature which include published financial data of each company on various mass media, annual reports for public companies, research reports from various securities, research reports from magazines and Bloomberg database particularly regarding mergers and acquisition transactions.

The data are panel data consisting of cross section data from an observed period of the year 2001-2011. Formulation of these variables is presented in table 1 . The data used in this study is panel data. Panel data are two-dimensional data and the combination of time dimension (time series) and individual company dimension (cross section).

All finance companies in Indonesia that published the financial statements in 2001 to 2011 are the objects of the research. The number of companies registered with Bapepam LK is one hundred and ninety-three companies. The sampling criteria are as follows:

1. Finance companies listed on the Capital Market and Financial Institution Supervisory Agency (Bapepam-LK) in 2011.

2. Finance companies that actively published financial statements during the period of 2001 to 2011.

3. Finance companies that announced the actions of corporate acquisitions during the period $2001-2011$ in various mass media channels or annual report.

The sampling unit is finance companies. The sampling frame is the list of companies listed on the Bapepam-LK and those that published financial statements for the period of 2001-2011. The sampling size is the total of all finance companies listed at the Bapepam-LK and met the specified criteria. This study uses purposive sampling with judgment sampling. Samples must meet certain criteria established in this study.

\section{Analysis and Discussion}

\subsection{Statistical Description}

Of the total sample of 100 companies that continously published financial statements from 2001 to 2011, data were collected as many as 1100 panel data. A total of $55.2 \%$ is a group of independent companies or a group of non-alliance and $44.8 \%$ is a group of integrated companies, both are in alliance with automotive related companies and banking industry.

Table 2. Distribution of Data

\begin{tabular}{llllll}
\hline & & Frequency & Percentage & Valid Percentage & $\begin{array}{l}\text { Cumulative } \\
\text { Percentage }\end{array}$ \\
\hline \multirow{3}{*}{ Valid } & Non Aligned & 607 & 55.2 & 55.2 & 55.2 \\
& Aligned & 493 & 44.8 & 44.8 & 100.0 \\
& Total & 1100 & 100.0 & 100.0 & \\
\hline
\end{tabular}

\section{Growth Ratio}

For total asset growth (TAGR), finance companies reached an average growth of 1.61 times during 2001 to 2011 , compared to the previous year. There were finance companies that did not experience growth, and also those that experienced growth up to 206 times of total asset from the previous year.

Productive asset growth (PAGR) experienced a higher average growth compared to asset growth which was equal to 2.87 times. As for the net income growth (NIGR), finance companies achieved net income growth of 2.27 times on average compared to the previous year. There were several finance companies that suffered declining net profit by -69.26 times and there were some that reached a maximum profit growth of 435.64 times. Revenue growth (REGR) of finance companies reached 2.23 times increase during the period of the study.

\section{Efficiency Ratio}

On average, finance companies have a ratio structure of productive assets to total assets (PATA) that amounts to $76 \%$. This achievement is higher than government regulations which regulate a minimum of $40 \%$. In terms of operating costs, finance companies have a ratio of operating expenses to operating income (EXIR) of 1.74 times. The high level of EXIR shows that finance companies also generate income other than interest income. Other income includes insurance sales revenue, fines revenue due to customer tardiness, customer installment payments 
and other income. Meanwhile, the operating costs of productive assets (EXPA) in finance companies reach 55\% on average. The growth of operating costs (EXGR) experienced a growth of 2.13 times on average compared to the previous year.

\section{Solvency Ratio}

For solvency ratio, the ratio of debt to total assets (LITA) reached 0.80 times on average. The ratio of debt to equity (Leverage / LEV) reached 0.32 times on average. This leverage is still relatively low compared to those allowed by the regulation, which is up to 10 times. However, there are finance companies that have negative equity, which results in a negative Leverage ratio.

\section{Risk Ratio}

For uncollectible receivables provisioning (PROV), finance companies reserve a provision of $3.84 \%$. In tax policy, finance companies are allowed to do the uncollectible receivables provisioning amounting to $2,5 \%$ for business leasing and $5 \%$ for consumer financing.

\section{Size Ratio}

On average, the total assets (FSI) of finance companies reached Rp. 12 billion per company. This average value is the average total assets from 2001 to 2011. The largest finance company has asset of Rp. 18 Trillion.

Table 3. Statistical Description

\begin{tabular}{llllll}
\hline & $\mathbf{N}$ & Minimum & Maximum & Mean & Std. Deviation \\
\hline EXIR & 1100 & -.467 & 316.667 & 1.74638 & 11.867538 \\
ROA & 1100 & -9.560 & 26.127 & .06042 & .910083 \\
ROE & 1100 & -61.075 & 29.843 & .10366 & 2.260085 \\
NPM & 1100 & -16.177 & 7.536 & .03550 & .697311 \\
PROV & 1100 & -1.095 & 4.518 & .03846 & .226607 \\
LEV & 1100 & -3265.617 & 296.094 & .32867 & 99.065149 \\
PATA & 1100 & .000 & 1.764 & .75556 & .231468 \\
LIQ & 1100 & .000 & 1077.571 & 6.93379 & 42.585406 \\
EXPA & 1100 & -.535 & 201.628 & .55306 & 6.142197 \\
REPA & 1100 & -.407 & 19.015 & .40063 & .803798 \\
LITA & 1100 & .000 & 159.125 & .80408 & 4.823126 \\
FSI & 1100 & .000 & 16.739 & 12.13712 & 2.074309 \\
TAGR & 1100 & .000 & 206.220 & 1.60684 & 6.584531 \\
PAGR & 1100 & .000 & 856.499 & 2.87197 & 27.539283 \\
NIGR & 1100 & -69.258 & 435.643 & 2.27138 & 18.305991 \\
REGR & 1100 & -.390 & 352.090 & 2.22665 & 12.537235 \\
EXGR & 1100 & -3.079 & 456.272 & 2.13496 & 15.136933 \\
Valid N (listwise) & 1100 & & & & \\
\hline
\end{tabular}

\section{Liquidity Ratio}

The liquidity ratio (LIQ) of financing receivables to debts comparison is 6.93 times on average. This value reflects a fairly liquid state, where each Rp. 1 of the debt is born by Rp. 6.93 .

\section{Profitability Ratio}

In terms of profitability, finance companies have a return on assets (ROA) of $6.04 \%$ on average. This value is categorised as high compared to other financial industries. As for the return on equity (ROE), the average reached $10.37 \%$. This average value of ROE is relatively low compared to the Indonesia investors' expectations of return.

As for the Net Profit Margin (NPM), finance companies have a Net Profit Margin of 3.55\% on average and operating income to earning assets (REPA) of $40.06 \%$. REPA shows numerous customer financing portfolios on two-wheel motor vehicles and electronics. On consumer vehicle financing, finance companies charge interest and administrative costs around $40 \%$ effectively per year. 


\subsection{Differences in Financial Performances}

The results of data processed for several ratio measurements shows significant differences between integrated and independent finance companies. Data processing uses non-parametric tests (Mann Whitney) and parametric tests (panel data).

Table 4. The Testing Result of Differences in Financial Performance

\begin{tabular}{|c|c|c|c|c|c|c|}
\hline \multirow{3}{*}{$\begin{array}{l}\text { Equation } \\
\text { EXIR }\end{array}$} & \multirow{2}{*}{\multicolumn{2}{|c|}{ Non Parametric (Mann Whitney) }} & \multicolumn{4}{|c|}{ Parametric (Pooled Least Squared) } \\
\hline & & & \multicolumn{2}{|l|}{ Model 1a } & \multicolumn{2}{|l|}{ Model 1b } \\
\hline & -4.167 & $* * *$ & $\begin{array}{l}-1.645 \\
(0.722)\end{array}$ & $* *$ & $\begin{array}{l}-1.155 \\
(0.773)\end{array}$ & \\
\hline EXPA & -1.301 & & $\begin{array}{l}-0.312 \\
(0.372)\end{array}$ & & $\begin{array}{l}-0.131 \\
(0.431)\end{array}$ & \\
\hline EXGR & -1.065 & & $\begin{array}{l}-1.218 \\
(0.917) \\
\end{array}$ & & $\begin{array}{l}-1.523 \\
(1.063) \\
\end{array}$ & \\
\hline PATA & -6.441 & $* * *$ & $\begin{array}{l}0.065 \\
(0.014) \\
\end{array}$ & $* * *$ & $\begin{array}{l}0.001 \\
(0.012)\end{array}$ & \\
\hline ROA & -3.398 & $* * *$ & $\begin{array}{l}-0.016 \\
(0.055) \\
\end{array}$ & & $\begin{array}{l}0.015 \\
(0.063) \\
\end{array}$ & \\
\hline ROE & -6.601 & $* * *$ & $\begin{array}{l}-0.002 \\
(0.137) \\
\end{array}$ & & $\begin{array}{l}0.043 \\
(0.156) \\
\end{array}$ & \\
\hline NPM & -2.735 & $* * *$ & $\begin{array}{l}0.074 \\
(0.042) \\
\end{array}$ & * & $\begin{array}{l}0.079 \\
(0.047) \\
\end{array}$ & $*$ \\
\hline REGR & -0.149 & & $\begin{array}{l}-1.371 \\
(0.759) \\
\end{array}$ & * & $\begin{array}{l}-14.083 \\
(0.880) \\
\end{array}$ & \\
\hline REPA & -0.244 & & $\begin{array}{l}0.088 \\
(0.048) \\
\end{array}$ & * & $\begin{array}{l}0.164 \\
(0.054) \\
\end{array}$ & $* * *$ \\
\hline PROV & -5.409 & $* * *$ & $\begin{array}{l}0.017 \\
(0.014) \\
\end{array}$ & & $\begin{array}{l}0.026 \\
(0.015) \\
\end{array}$ & $*$ \\
\hline LIQ & -5.415 & $* * *$ & $\begin{array}{l}-8.952 \\
(2.568) \\
\end{array}$ & $* * *$ & $\begin{array}{l}-5.667 \\
(2.883) \\
\end{array}$ & $*$ \\
\hline LEV & -8.776 & $* * *$ & $\begin{array}{l}5.983 \\
(6.001) \\
\end{array}$ & & $\begin{array}{l}6.936 \\
(6.967)\end{array}$ & \\
\hline LITA & -6.763 & $* * *$ & $\begin{array}{l}-0.199 \\
(0.292) \\
\end{array}$ & & $\begin{array}{l}-0.147 \\
(0.339) \\
\end{array}$ & \\
\hline FSI & -11.659 & $* * *$ & $\begin{array}{l}1.294 \\
(0.119) \\
\end{array}$ & $* * *$ & $\begin{array}{l}0.234 \\
(0.051) \\
\end{array}$ & $* * *$ \\
\hline TAGR & -1.621 & & $\begin{array}{l}-0.229 \\
(0.399) \\
\end{array}$ & & $\begin{array}{l}-0.312 \\
(0.463) \\
\end{array}$ & \\
\hline PAGR & -1.633 & $*$ & $\begin{array}{l}-0.811 \\
(1.669)\end{array}$ & & $\begin{array}{l}-0.178 \\
(19.345)\end{array}$ & \\
\hline NIGR & -1.988 & $* *$ & $\begin{array}{l}0.005 \\
(1.110)\end{array}$ & & $\begin{array}{l}0.118 \\
(128.677)\end{array}$ & \\
\hline
\end{tabular}

Note:

1) Dummy estimation coefficient ( 1 for integrated companies and 0 for independent companies)

2) Numbers in ( ) states the estimated standard error

3) *) Significant at $\alpha=10 \%$

**) Significant at $\alpha=5 \%$

***) Significant at $\alpha=1 \%$

The significant results of Pooled Least Squared (PLS) will be re-tested using Fixed Effect Model (FEM) dan Random Effect Model (REM) test. Afterwards, The Chow test, Hausman test and LM test will be used to compare the results between PLS and FEM, between REM and FEM and between PLS and REM respectively. 
Table 5. Panel Data Test Results

\begin{tabular}{|c|c|c|c|c|c|c|c|c|c|c|c|c|c|}
\hline \multirow{2}{*}{ Equation } & \multicolumn{6}{|c|}{ Model 1 a } & \multicolumn{6}{|c|}{ Test } & \multirow{2}{*}{$\begin{array}{c}\text { Selected } \\
\text { Model }\end{array}$} \\
\hline & PLS & & FEM & & REM & & Chow & & Hausma & & $\mathbf{L M}$ & & \\
\hline EXIR & -1.645 & $* *$ & 0.091 & & -1.493 & & 2.770 & $* * *$ & 0.350 & & 103.800 & $* * *$ & PLS \\
\hline PATA & 0.065 & $* * *$ & 0.013 & & 0.055 & $* *$ & 5.460 & $* * *$ & 0.890 & & 448.590 & $* * *$ & REM \\
\hline NPM & 0.074 & $*$ & -0.104 & & 0.069 & & 1.580 & $* * *$ & 1.030 & & 12.660 & $* * *$ & PLS \\
\hline REGR & -1.371 & $*$ & -6.888 & $* *$ & -1.372 & $*$ & 0.970 & & 2.970 & $*$ & 0.220 & & FEM \\
\hline REPA & 0.088 & $*$ & -0.126 & & 0.069 & & 2.860 & $* * *$ & 1.170 & & 111.160 & $* * *$ & PLS \\
\hline LIQ & -8.952 & $* * *$ & 0.516 & & -8.451 & & 2.030 & $* * *$ & 0.790 & & 38.590 & $* * *$ & PLS \\
\hline FSI & 1.294 & $* * *$ & 1.369 & $* * *$ & 1.326 & $* * *$ & 15.220 & $* * *$ & 0.030 & & $1,734.000$ & $* * *$ & REM \\
\hline \multirow{2}{*}{ Equation } & \multicolumn{6}{|c|}{ Model 1 b } & \multicolumn{6}{|c|}{ Test } & Selected \\
\hline & PLS & & FEM & & REM & & Chow & & Hausma & & $\mathbf{L M}$ & & Model \\
\hline NPM & 0.079 & * & -0.038 & & 0.082 & & 1.740 & $* * *$ & 7.780 & $*$ & 17.460 & $* * *$ & PLS \\
\hline REPA & 0.164 & $* * *$ & -0.027 & & 0.153 & $*$ & 2.800 & $* * *$ & 1.510 & & 101.100 & $* * *$ & REM \\
\hline PROV & 0.026 & $*$ & 0.061 & & 0.027 & & 1.670 & $* * *$ & 1.050 & & 17.030 & $* * *$ & PLS \\
\hline LIQ & -5.567 & $*$ & 2.418 & & -5.598 & & 1.630 & $* * *$ & 2.680 & & 14.210 & $* * *$ & PLS \\
\hline
\end{tabular}

Note: 1)*) Significant at $\alpha=10 \%$

**) Significant at $\alpha=5 \%$

$* * *$ ) Significant at $\alpha=1 \%$

2) PLS: Pooled Least Squared; FEM: Fixed Effect Model; REM: Random Effect Model

\subsubsection{The Results of Testing H1 (Growth Ratio)}

In terms of productive asset growth (PAGR), a statistical value of -1.633 is obtained with $\alpha=10 \%$ by using non-parametric test. These results show that there are real differences between PAGR ratio of integrated and independent finance companies. PAGR ratio of integrated finance companies is greater than those of independent finance companies. It shows that the integrated companies have a greater asset growth than independent finance companies. This growth is supported by the parent of finance companies.

For growth in net income (NIGR), the test results using the non-parametric Mann Whitney test reach a statistical value of -1.988 and is significant at $\alpha=5 \%$. These results show there are apparent differences between NIGR ratio of integrated and independent finance companies. NIGR ratio of integrated finance companies is higher than those of independent finance companies. This shows that the integrated companies have a higher net profit growth than independent companies.

NIGR ratio shows a net profit growth of finance companies compared to the previous year. The higher this ratio, the higher the profit growth will be, and the better the finance company will be.

For earnings growth ratio (REGR), the test results by using the parametric test (Fixed Effect Model) obtains a statistical value of -6.888 and is significant at $\alpha=10 \%$. These results show there are apparent differences between REGR ratio of integrated and independent finance companies. The REGR ratio of integrated finance companies is lower than independent finance companies. This shows that the integrated companies have a lower revenue growth compared to independent finance companies. The results are consistent with findings by Beijerse (2000). Increase in organic growth is more focused on core competencies and capabilities in order to meet customer needs.

REGR ratio shows revenue growth of finance companies compared to the previous year. The higher this ratio is, the better a finance company will be.

\subsubsection{The Results of Testing H2 (Efficiency)}

Based on non-parametric approach using the Mann Whitney test (MW), a statistical value of MW test is obtained for the variable Operating Expenses Operating Income (EXIR) of -4.167 and is significant at $\alpha=1 \%$. The same is showed by a parametric test (pool least square) where the dummy variable (integrated-independent) reaches a value of -1.645 and is significant at $\alpha=5 \%$. The results explain that on average there are significant EXIR performance differences between integrated and independent finance companies, and that on average, the EXIR 
value of integrated companies is smaller than independent companies. This means that the integrated companies are more efficient that independent companies.

EXIR shows a comparison between operating costs and operating income. This variable measures the efficiency level of a financial institution. The lower this ratio is, the more it shows higher efficiency compared to other institutions.

For the productive asset structure to total assets (productive assets to total assets / PATA) aspect, it is tested with Mann Whitney and a statistical value of -6.441 is obtained and is significant at $\alpha=1 \%$. The same is showed by a parametric test (Random Effect Model) where the dummy variable (alliance-non-alliance) is worth 0.055 and is significant at $\alpha=5 \%$. The results explain that on average there are significant performance differences between integrated and independent finance companies. The test results also show that on average, the PATA value of integrated companies is greater than independent companies. It also means that the integrated companies are more efficient in asset allocation compared to independent companies.

PATA shows a comparison between the productive assets and total assets. This variable measures the level of efficiency of a financial institution in asset allocation. The higher this ratio is, the more efficient the company allocates its productive assets compared to other assets.

These results are in line with the results of Healey (1990) who found that mergers and acquisitions will increase the productivity as compared to the average achievement of the industry. Similar results were also found by Becalli (2008) who found that mergers and acquisitions achieve more efficiencies in operations compared to its industry average.

\subsubsection{The Results of Testing H3 (Solvency)}

The capital structure aspect or leverage (LEV) is tested with the Mann Whitney and a statistical value -8.776 is obtained and significant at $\alpha=1 \%$. The results explain that on average there are significant differences between integrated and independent finance companies terms of leverage ratio. Companies in alliance with either with the banking or automotive related companies have stronger capital support compared to finance companies with no alliance. This results in a higher leverage on integrated finance companies.

Leverage ratio becomes a way to measure performance of finance companies as stipulated in the Decree of the Minister of Finance. Maximum leverage ratio allowed is 10 times of the equity.

For liabilities to total assets ratio (LITA), the test results by using the non-parametric Mann Whitney obtain a statistical value of -6.763 with $\alpha=1 \%$. These results show there are apparent differences between LITA ratios of integrated and independent finance companies. LITA ratio of integrated finance companies is higher than independent finance companies. This shows that the integrated finance companies have more efficient capital structure than independent finance companies. Ease in obtaining loan funds becomes the advantage of integrated finance companies.

Liablities to total asset (LITA) ratio shows a comparison of total debt ratio to total assets of a finance company. The higher this ratio is, the higher the risk a finance company will have.

\subsubsection{The Results of Testing H4 (Asset Quality)}

On risk management aspect, the ratio of provisioning (uncollectible receivables provisioning) is tested with Mann Whitney and a statistical value of 5.409 is obtained and significant at $\alpha=1 \%$. The results show that on average, integrated finance companies have a significant difference for the uncollectible receivables provisioning ratio compared to independent finance companies. Integrated finance companies have more stringent provisioning policies than independent companies. A finance company in alliance with a bank or a bank holding company has an obligation to follow the standard banking provisioning regulation by Bank Indonesia. This is consistent with the financing cooperation (joint financing) among finance companies in alliance with banks, where the composition of funding between the two parties ranges from 1\% until $99 \%$ to $10 \%$ until $90 \%$. This is consistent with the results of studies by Mandelker (1972). Mandelker found that the acquisition and the merger would cause a risk to the company.

\subsubsection{The Results of Testing H5 (Firm Size)}

By Mann Whitney test (MW), a statistical value of -11.659 is obtained for the variable Firm Size (FSI) and is significant at $\alpha=1 \%$. The same is shown by a parametric test (Random Effect Model) where the dummy variable (integrated-independent) is worth 1.326 and significant at $\alpha=1 \%$. By adding a variable lag (1) on firm size and asset growth in parametric testing (pooled least squares), firm size aspects reach 0.234 statistical value with $\alpha=1 \%$. These results show there are apparent differences between Firm Size ratio of integrated and independent finance 
companies. FSI ratio of integrated companies is greater than independent finance companies, both by non-parametric and parametric testing. FSI ratio shows total assets ratio of finance companies. The higher this ratio is, the bigger a finance company will be.

\subsubsection{The Results of Testing H6 (Liquidity)}

With non-parametric testing, aspects of liquidity (LIQ) is tested with the Mann Whitney and a statistical value of -5.415 is obtained while a statistical value of -8.952 is obtained using parametric test; both are significant at $\alpha=1 \%$. By adding a lag factor (1) on firm size and asset growth in parametric testing (pooled least square), the liquidity aspect obtains the value of -5.567 with $\alpha=10 \%$. These results show there are real differences between the performances of liquidity in integrated and independent finance companies. Integrated finance companies' current ratio is lower than the independent finance companies. This explains a more efficient rate on integrated finance companies.

Liquidity ratio shows the comparison between productive assets and total debt. This variable measures the number of productive assets of finance companies that can be used to cover the debts of finance companies. The higher this ratio is, the more liquid a finance company is.

\subsubsection{The Results of Testing H7 (Profitability)}

In terms of profitability, Return on Assets (ROA) and Return on Equity (ROE) are tested by Mann Whitney (MW) and statistical values of -3.398 for the ROA and -6.601 for the ROE are obtained and are significant at $\alpha=1 \%$. The results explain that on average there are significant differences between the performance of ROA and ROE of integrated and independent finance companies. The average ROA and ROE of integrated finance companies are greater than the independent companies or they are more profitable than independent companies. This is consistent with research findings by Kemmpi et al. (2008) and Kling et al. (2009).

ROA indicates the return on total assets managed by a company. ROE shows return on shareholder investment in the finance company's equity. The higher these ratios are, the better the return is.

In terms of Net Profit Margin (NPM) which is tested with Mann Whitney test, a statistical value of -2.735 is obtained and is significant at $\alpha=1 \%$. The same result is indicated by a parametric test (pooled least squared) with statistical value of 0.074 with a dummy variable and is significant $\alpha=10 \%$. By adding variable lag (1) for firm size and lag (1) for asset growth, a statistical value of 0.079 is obtained and is significant at $\alpha=1 \%$. These results show that on average there is a difference between the NPM of integrated and independent finance companies. NPM of integrated finance companies is greater than independent finance companies. Integrated companies will have the power in funding especially those that are in alliance with banks. Finance companies that ally with automotive related companies will get a special promotional subsidy from its parent company.

For the ratio of operating income to productive assets (REPA), the test results by using the parametric test (Pooled Least Squared) and inserting a lag (1) variable for firm size and asset growth reach a statistical value of 0.088 and 0.153 with $\alpha=10 \%$. The results show that there are real differences between REPA ratio of integrated and independent companies. REPA ratio is higher in integrated companies than independent companies. This shows a more efficient level in integrated companies.

REPA ratio shows the return of productive assets / financing receivables or income derived from financing receivables. The higher this ratio is, the better a finance company will be.

\section{Conclusion}

This paper investigates whether related parent company influences the performance of finance company. Using a sample of 100 finance companies which published their financial statement over the period 2001-2011, we analyse whether parent company's value are reflected in improved performance of the finance company subsidiary. (measured using standard accounting ratios). The related parent company is categorized into 2 group which are banking industry and automotive industry. Banking industry provide the funding and automotive industry provide the product of financing to finance company. The integration with banking industry called as backward integration and the integration with automotive industry called as forward integration.

With the series of M\&A taking place in financial sector in Indonesia, the target finance company owned by the related industry showed improved in expense to income ratio (EXIR), productive asset allocation (PATA), profitability (ROA and ROE), bigger firm size and higher growth in productive asset and net income Also, it has improved the net profit margin of the finance company. The integrated finance company also showed more conservative by putting higher reserve. However, the integrated finance companies have higher leverage, higher liabilities to total asset lower liquidity and lower in revenue growth. Overall, the result of the study indicates that in 
the long run the acquiring firms are able to generate value creation in one or the other form such as operation efficiency, profitability, firm size and higher growth capabilities.

\section{References}

Akhavein, J. D., Berger, A. N., \& Humprey, D. B. (1997). The effect of megamergers on efficiency and prices:evidence from a bank profit function. Review of Industrial Organisation, 12, 95-139. http://dx.doi.org/10.1023/A:1007760924829

Aktas, N., Bodt, E. D., \& Samaras, V. (2008). Do acquisitions and internal growth impact differentially firm performance? SIFF Conference (Paris, 2007), the LSM Ph.D Workshop (Mons, 2007) and the EFMA Conference (Athens, 2008).

Asosiasi Leasing Asia, ALFA World. (2009). Annual Report, download from www.alfaworld.or.id.

Asosiasi Perusahaan Pembiayaan Indonesia. (APPI). (2005-2009). Annual Report download from www.ifsa.or.id.

Bapepam, L. K. (2005-2009). Annual Report. Bapepam, Menteri Keuangan Republik Indonesia.

Beccalli, E., \& Pascal, F. (2008). Merger and Acquisition Operations and Performance in Banking. London School of Economics. Journal of Financial Services Research, 36(2-3), 203-226. http://dx.doi.org/10.1007/s10693-008-0051-6

Beijerse, R. P. (2000). Knowledge Management in Small and Medium-sized Companies: Knowledge Management for Entrepreneurs. Journal of Knowledge Management, 4(2), 162-179. http://dx.doi.org/10.1108/13673270010372297

Berger, A. N., \& Humphrey, D. B. (1997). Efficiency of financial institutions: International survey and directions for future research. European Journal of Operational Research, 98, 175-212. http://dx.doi.org/10.1016/S0377-2217(96)00342-6

Berger, A. N., Demsetz, R., \& Straham, P. E. (1999). The Consolidation of Financial Services Industry: Causes, Conseques and Implication for the Future. Journal of Banking and Finance, 23, 135-194. http://dx.doi.org/10.1016/S0378-4266(98)00125-3

Berger, A. N., DeYoung, R., Genay, H., \& Udell, G. F. (2000). Globalization of Financial Institutions:Comments and Discussion Evidence from Cross-Border Banking Performance. Brookings-Wharton Papers on Financial Services, 23-120. http://dx.doi.org/10.1353/pfs.2000.0001

Chang, S. Y., \& Ariff, M. (2006). Firm Characteristics, Long-Run Operating Performance, and Economic Efficiency Changes in Australian Takeovers. The 14th Conference on the Theories and Practices of Securities and Financial Markets.

Cheng, C. L. (2006). Financial sector consolidation events and post consolidation performance results: Evidence from Taiwan banking industry. PhD Dissertation. Claremont Graduate University, Claremont, California, United State. Retrieved March, 20, 2011 from ABI/INFORM Global database.

Cornet, M. M., McNutt, J. J., \& Tehranian, H. (2006). Performance changes around bank mergers: Revenue enhancement versus cost reductions. Journal Money Credit Bank, 38, 1013-1050. http://dx.doi.org/10.1353/mcb.2006.0053

Cornet, M. M., \& Tehranian, H. (1992). Changes in Corporate Performance Associated with Bank Acquisitions. Journal of Financial Economics , 31, 211-234. http://dx.doi.org/10.1016/0304-405X(92)90004-H

Haugen, R. A., \& Langetieg, T. C. (1975). An Empirical Test For Synergism In Merger. The Journal of Finance, XXX(4), 1003 -1014. http://dx.doi.org/10.1111/j.1540-6261.1975.tb01017.x

Healey, P. M., Palepu, K. G., \& Ruback, R. S. (1992). Does Corporate Performance improve after mergers? Journal of Financial Economics, 31, 135-175. http://dx.doi.org/10.1016/0304-405X(92)90002-F

Hutabarat, M. (2012). Comparative Study on Regulation and Control Non Bank Financial Institution - Finance Company. Bapepam LK-Mazars-USAID.

Infobank, Magazine. (2005, 2006, 2007, 2008, 2009, 2010, 2011). Rating Multifinance, PT. Infoartha Pratama.

Investor, Magazine. (2007, 2008, 2009, 2010). Best Multifinance Company, PT. Global Media.

Kemppi, K., Patari, S., Jantunen, A., \& Kylaheiko, K. (2008). Growth Strategies and Their Effects on Firm Performance - Empirical Analysis in the Global Pulp and Paper Industry. School of Business, Lappeenranta University of Technology, Finland. 
Kling, G., Ghobadian, A., \& O'Regan, N. (2009). Organic Growth and Shareholder value: A case study of the insurance industry. International Journal of Research in Marketing, 26(4), 276-283. http://dx.doi.org/10.1016/j.jijresmar.2009.08.002

Langetieg, T. C., Haugen, R. A., \& Wichern, D. W. (1980). Merger and Stockholder Risk. The Journal of Financial and Quantitative Analysis, 15(3), 689-717. http://dx.doi.org/10.2307/2330404

Mandelker, G., \& Lev, B. (1972). The Microeconomic Consequences of Corporate Mergers. The Journal of Business.

Nuryartono, N. (2012). Comparative Study on Regulation and Control Non Bank Financial Institution - Finance Company. Bapepam LK - Mazars, Bidakara Hotel

Schweiger, D. M., \& Very, P. (2003). Creating Value Through Merger and Acquisition Integration. Advances in Mergers and Acquisitions, 2, 1-26. http://dx.doi.org/10.1016/S1479-361X(03)02002-7

Singh, H., \& Montgomery, C. A. (1987). Corporate Acquisition Strategies and Economic Performance. Strategic Management Journal, 8, 377-386. http://dx.doi.org/10.1002/smj.4250080407

Vander-Vennet, R. (1996). The effect of mega mergers and acquisitions on the efficiency and profitability of EC credit institutions. Journal of Banking and Finance, 20, 1531-1558. http://dx.doi.org/10.1016/S0378-4266(96)00014-3

Vander-Vennet, R. (2002). Cross-border mergers in European banking and bank efficiency. Faculteit Ecnomie En Bedrijfskunde.

Wang, H. (2007). Strategic alliances by financial services firms. Doctor of Business Administration Disertation. Louisiana Tech University United State. Retrieved March, 20, 2011 from ABI/INFORM Global database. (Published No. UMI 3270945)

Zhang, J. (2006). Efficiency gains from bank consolidations. (1999-2005). PhD. Disertation. Graduate School of Wayne State University, Detroit, Michigan, United State. Retrieved March, 20, 2011 from ABI/INFORM Global database. (Published No. UMI 3243068) 